\section{Geographic and socioeconomic distribution of food vendors: a case study of a municipality in the Southern Brazil}

\author{
Distribuição geográfica e socioeconômica de \\ comerciantes de alimentos: um estudo de caso \\ de um município no Sul do Brasil
}

\section{Distribución geográfica y socioeconómica de comerciantes de alimentos: un estudio de caso de un municipio en el sur de Brasil}

\section{Abstract}

The objective of this study was to identify the food vendor distribution profile of the city of Florianópolis, Santa Catarina State, Brazil, and investigate its association with the socioeconomic and demographic characteristics of different municipal regions. This descriptive, cross-sectional study obtained the location of food vendors from secondary data from different institutional sources. The density of different types of food vendors per 1,000 inhabitants in each municipal weighted area was calculated. The Kruskal-Wallis test compared the mean density of food vendors and the weighted income areas. The lowestincome regions had the lowest density of butchers, snack bars, supermarkets, bakeries/pastry shops, natural product stores, juice bars, and convenience stores. The identification of these areas may encourage the creation of public policies that facilitate healthy food startups and/or maintenance of healthy food vendors, especially in the lowest-income regions.
\end{abstract}

Products Commerce; Urbanization; Food
Elizabeth Nappi Correa 1

Cristina Maria Proença Padez 2

Ângelo Horta de Abreu 3

Francisco de Assis Guedes de Vasconcelos 1

doi: 10.1590/0102-311X00145015

\section{Correspondence}

E. N. Correa

Departamento de Nutrição, Centro de Ciências da Saúde, Universidade Federal de Santa Catarina.

Campus Reitor João David Ferreira Lima s/n, Trindade, Florianópolis - SC, 88040-900, Brasil.

nutrinappi@gmail.com

1 Centro de Ciências da Saúde, Universidade Federal de Santa Catarina, Florianópolis, Brasil.

2 Centro de Investigação em Antropologia e Saúde, Universidade de Coimbra, Coimbra, Portugal.

3 Faculdade de Letras, Universidade de Coimbra, Coimbra, Portugal. 


\section{Introduction}

Obesity has reached epidemic levels according to the World Health Organization (WHO). A nationwide Brazilian survey conducted in 2008-2009 found adult overweight and obesity rates of $34.2 \%$ and $14.8 \%$, respectively; adolescent (ages 10 to 19 years) overweight and obesity rates of $15.6 \%$ and $4.9 \%$, respectively; and child (ages 5 to 9 years) overweight and obesity rates of $19.2 \%$ and $14.3 \%$, respectively 1 .

The prevalences in the Municipality of Florianópolis, Santa Catarina State, presented small variations when compared with the rest of the country. In 2013, 33.2\% and $15.4 \%$ of adults were overweight and obese, respectively 2 . In $201218.9 \%$ and 8.5\% of adolescents aged 13 to 15 years were overweight and obese, respectively 3 ; and $34.2 \%$ of children and adolescents aged 7 to 14 years were overweight or obese 4 .

The literature shows that the risk of obesity is not randomly distributed in the population 5 . Health problems with complex etiologies, such as obesity, involve individual and environmental characteristics 5. Changes in food patterns, including higher consumption of processed foods with high sugar, sodium, and fat contents, along with a sedentary lifestyle are the underlying causes of the overweight and obesity epidemic 1 .

Strategies that promote healthy life habits emphasize the importance of a varied diet 6,7. However, interest in studying the food environment has been growing since the 1990s, which may facilitate or impair the adoption of healthy food habits $8,9,10,11,12$.

The availability and easy access to cheap, fresh, and good-quality healthy foods in the neighborhood may be considered determinants of healthier food habits and consequently, promote body weight control 10,11,13. Nonetheless, the availability of and access to these foods may vary greatly between neighborhoods or regions 14 .

People who live close to healthy food vendors may increase their intake of fruits and vegetables because it is easy to acquire healthier, perishable foods more frequently 15 . On the other hand, people who live in poor urban communities predominantly occupied by ethnic or socioeconomic minorities have to travel farther to buy cheap, healthy foods. And people who live in wealthier neighborhoods have easier access to supermarkets 16,17,18,19.

Urban spaces affect lifestyle choices, which reflect on health. Moreover, interventions that focus on the structure/environment, especially policies related to access to healthy foods, are a promising opportunity for people to effectively adopt healthier food habits. Thus, studies on the geographical/ spatial distribution of food vendors in a community are important, pertinent, and opportune for scientifically-backed strategies that promote healthy diets and fight obesity 6,11,20,21,22.

The city of Florianópolis experienced large population growth in recent decades. Although it is the Brazilian state capital with the highest Municipal Health Development Index (MHDI), at 0.847 (very high) in 201023 , and has a higher gross domestic product (GDP) per capita than the national mean, compatible with middle-income countries 24 , investments have focused on certain municipal regions. Intensification of urbanization may also be perceived by the unequal distribution of public and private resources in the municipality 25

Recognizing the distribution profile of food vendors in Florianópolis will help one to partly understand the extent to which comparisons with Brazilian and foreign studies are possible. The objective of this study was to identify the location of food vendors in the Municipality of Florianópolis and to investigate the association between their distribution and the socioeconomic characteristics of each municipal region.

\section{Material and methods}

This descriptive, cross-sectional study used secondary data from different institutional sources. To create the database, we first requested the records of the Sanitary and Environmental Surveillance Management of Florianópolis' Municipal Department of Health (VISA Floripa), which contains information about municipal food vendors in 2013, such as their name, address (street, neighborhood, 
and ZIP code), and type of establishment according to the criteria established by Florianópolis' city hall for the payment of taxes related to municipal health surveillance actions. The entire municipal geographic area was considered, including the insular and continental areas.

Nevertheless, since this list could be incomplete, data from different sources were triangulated to check and possibly update the original data 26.

The following data verification and updating strategies were used:

(a) Consultation to a printed version of the telephone directory 25 distributed in the municipality and to food vendor data listed in online telephone directories (http://www.hagah.com.br/; http:// www.guiafacil.com/florianopolis/sc/; and http://www.telelistas.net/sc/florianopolis). The following words were searched in Portuguese: restaurants, snack bars, pastry shops, candy shops, coffee shops, ice cream parlors, buffet restaurants, pizzerias, steakhouses, yogurt shops, pastelarias, bars, supermarkets, grocery stores, minimarkets, convenience stores, butchers, bakeries, seafood shops, and farmers' markets;

(b) Inclusion of the list of municipal street vendors. Street vendor location was obtained from the decree that regulates street food vending 27 ;

(c) Consultation of the list of municipal farmers' markets provided by the Executive Department of Public Services (SESP) of Florianópolis;

(d) Consultation of information about members of the Brazilian Association of Bars and Restaurants - Santa Catarina Section (ABRASELSC), and official sites of fast food chains (http://www.mcdonalds. com.br/; http://wwww.bobs.com.br/; http://www.burgerking.com.br/; and http://www.subway. com.br/) and supermarkets (http://www.supermercadosimperatriz.com.br/; http://www.angeloni. com.br/; http://www.superrosa.com.br/site/; http://www.hippo.com.br/; and http://www.bistek. com.br/rede_bistek) with outlets in Florianópolis and consultation of tourism and gastronomy websites about restaurants, bars, and snack bars (http://www.belasantacatarina.com.br/ and http:// vejabrasil.abril.com.br/santa-catarina).

(e) Identification of food vendors in the municipal shopping malls by consulting their official websites (http://www.shoppingbeiramar.com.br/; http://www.floripashopping.com.br/; http://www. iguatemi.com.br/florianopolis; http://www.macshopping.com.br/loja/; and http://www.jurere. com.br/jos/).

The printed version of the telephone directory is published annually, but the other sources of information are updated according to site need (joining of new members, old members leaving, or opening of new outlets, for example).

The study database did not include establishments classified by the VISA Floripa as bars, nightclubs, liquor stores, delivery-only food vendors, and in-house food providers, such as those in schools, companies, universities, hotels, hostels, gyms, sports clubs, and beauty parlors. Only establishments from chains with more than one store in the municipality were classified as supermarkets.

A single list of the food vendors was created manually. When a food vendor was listed in more than one source, the duplicate was excluded from the database. Once the verification and/or updating processes were completed, the food vendors were grouped into 15 categories: restaurant, snack bar, juice bar, ice cream parlor, candy shop, bakery/pastry shop, supermarket, grocery store, butcher, seafood shop, street food vendor, farmers' market, natural products store, convenience store, grocery store/meals. The present study defined street trading as the retail of goods (for example, candy, soda, popcorn, churros, and hot dogs, among others) 27.

In order to facilitate the analyses, the 15 food vendor categories were regrouped into only three categories: healthy food vendors (restaurant, butcher, seafood shop, farmers' market, natural products store, and juice bar); unhealthy food venders (snack bar, convenience store, candy shop, ice cream parlor, street food vendor); and mixed (healthy \& unhealthy) food vendors (supermarket, grocery store, bakery/pastry shop, and grocery store/meals).

Healthy food vendors were defined as those that sell fresh foods, minimally processed foods, or preparations with good nutritional quality. Unhealthy food vendors were defined as those that sell ultra-processed food products. Mixed food vendors were those that sell fresh foods or minimally processed foods and ultra-processed foods. This classification is based on the proposal made by Monteiro et al. 28,29 and adopted by the second edition of the Brazilian Food Guide ${ }^{7}$. 
Verification of food vendor ZIP codes, spelling, and full address was made at the official website of the Brazilian Company of Mail and Telegraph (http://www.buscacep.correios.com.br/). Later, using the address box of the software Google Earth (https://www.google.com/earth/), each food vendor was manually placemarked at the corresponding address (with the creation of a spacemark based on geographical coordinates). During this procedure, we also used the resource Street View to more accurately identify food vendor location. Street View allows the exploration of places through 360-degree, panoramic, and street-level imagery.

Google Earth captures images constantly via satellite. On the other hand, image updating in Google Street View depends on the company's schedule. In Florianópolis, Google Street View began capturing images in September 2011 (but did not cover the entire municipality). The lack of updated Street View data in many regions of the city may be a problem when using images in this auditing process 30 . Nevertheless, Google Street View was used for confirming the exact location of the food vendors. When the outlet was not seen, and the image was dated 2013 or later, the outlet was excluded.

During the manual placemarking stage, doubts regarding the address, name, type of service, and opening date were clarified by consulting the food vendor's registration status in specialized sites by looking up the active CNPJ (an official business registration number) of the companies and identifying the company name and type of activity. Additional Internet consultations (official websites and relationship sites) were also conducted to confirm a food vendor's activity and type of service provided, correcting the food vendor's category if necessary.

In order to characterize the distribution profile of the municipal food vendors, the demographic and socioeconomic data of Florianópolis' residents were obtained from the 2010 Census, which aggregated data from the 651 ( 605 urban and 46 rural) tracts of the census matrix of Florianópolis into 30 weighted areas 22 . The demographic data of the census tracts could not be used because of their statistical insignificance; in this case, the minimum analytical unit proposed by the Brazilian Institute of Geography and Statistics (IBGE) is the weighted area, consisting of a group of census tracts with statistically significant, usable results 24 .

The results are presented in the form of descriptive statistics, showing food vendor distribution by income level of each weighted area. The data and analyses of the weighted areas were divided into tertiles of mean nominal household income per month as follows: 1 st distribution tertile (1,395-2,180 USD); 2nd distribution tertile (2,181-3,021 USD); and 3rd distribution tertile (3,022-6,165 USD). The mean nominal household income per month for the municipality was 2,903 USD. The mean nominal incomes are expressed in Brazilian Real (BRL) by the IBGE, but converted into United States dollars (USD) for the study. The values were converted using the mean conversion rate of August 2010, when the 2010 Census started collecting data.

The density of food vendors in each area was calculated for every 1,000 inhabitants. The software ArcGIS (http://www.esri.com/software/arcgis/index.html) was used for constructing the thematic maps.

The statistical software Stata, version 13.0 (StataCorp LP, College Station, USA), performed the statistical analyses. It calculated measures of central tendency (mean) and dispersion (standard deviation). Sample distribution was verified first, making sure all variables had asymmetric distribution. The Kruskal-Wallis test compared the mean food vendor density. When the difference was statistically significant, the post Kruskal-Wallis test identified the differing categories. The measure of central tendency was used on variables with rank variation. All analyses considered the statistical significance level of $\mathrm{p}<0.05$.

\section{Results}

Figure 1 shows the distribution of the weighted areas by income tertiles. Generally, the areas with the highest income are located in the central and continental regions of the city, except for a region in the northern part of the island, where a high-end resort is located.

Florianópolis has a total of 2,555 food vendors, of which 1,202 sell healthy foods, 873 sell unhealthy foods, and 480 sell healthy and unhealthy foods. In the weighted lower-income areas, there were 214 healthy food vendors, 146 unhealthy food vendors, and 152 mixed food vendors. In medium-income 


\section{Figure 1}

Weighted areas of Florianópolis, Santa Catarina State, Brazil, in 2010 according to the mean nominal income per month of private households in United States dollars (USD).

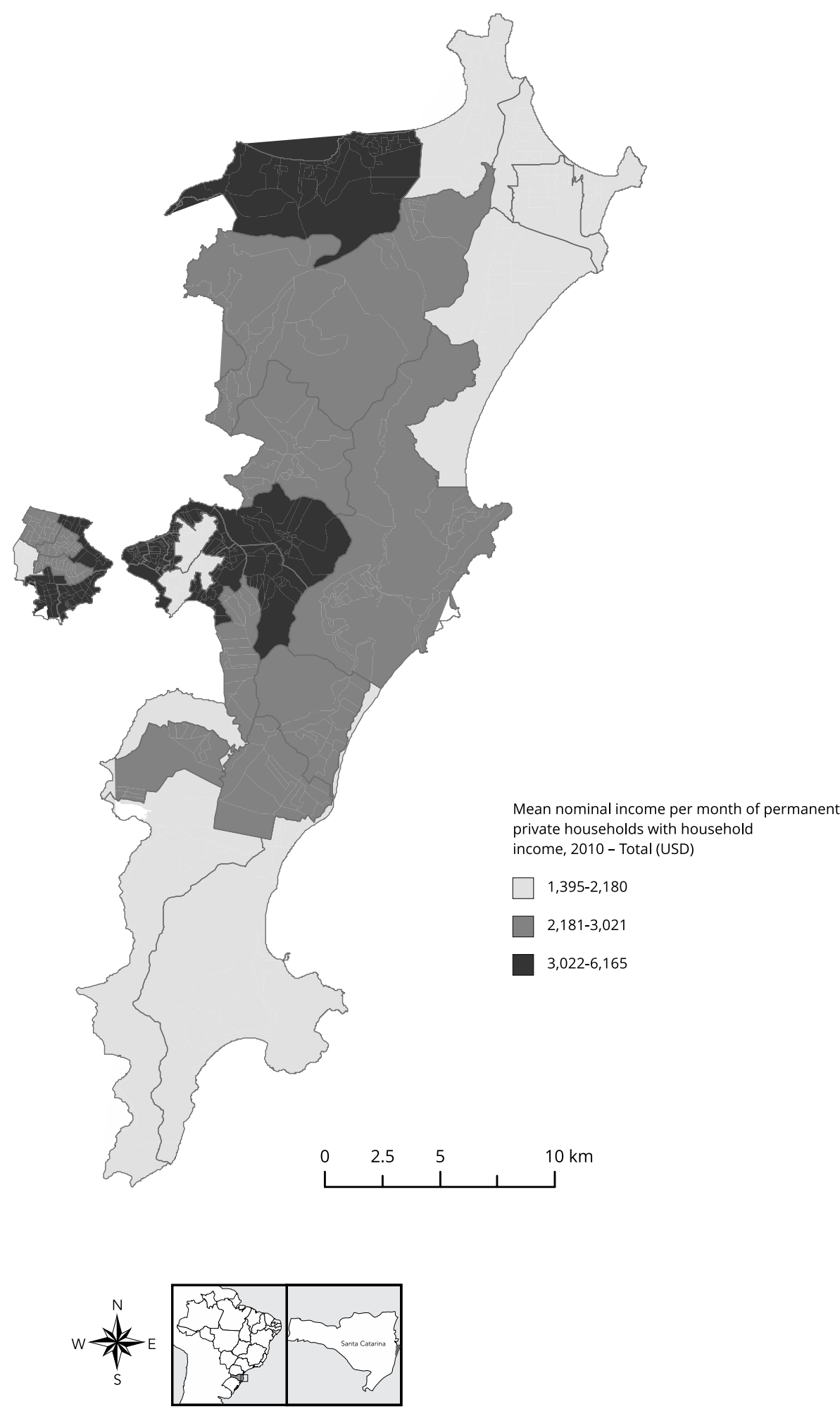


areas, the numbers of healthy, unhealthy, and mixed food vendors were 417, 223, and 155, respectively. In high-income areas, the numbers of healthy, unhealthy, and mixed food vendors were 517, 504, and 173 , respectively. The data show a higher absolute number of food vendors of the three types in weighted areas in the higher income tertile.

Food vendor density per 1,000 inhabitants showed that lower-income areas have fewer food vendors (Figure 2), except for mini markets and fishmongers, whose densities were higher in areas in the lowest income tertile. Generally, restaurants and snack bars had higher densities.

Table 1 presents the mean density of healthy, unhealthy, and mixed food vendors by tertiles of mean nominal household income. For healthy food vendors, only the density of butcheries was statistically different in higher-income regions. The density of unhealthy food vendors, in general and snack bars, was also higher in regions in the highest income tertile. Likewise, the density of mixed food vendors (supermarkets and bakeries) was significantly higher in regions with higher purchasing power.

Figure 3 shows the tertiles of density distribution per 1,000 inhabitants of healthy, unhealthy, mixed food vendors, and all food vendors in the weighted areas. Generally, the downtown-north axis of the island had the highest density of healthy food vendors. Likewise, the eastern region of the municipality, where the most touristic neighborhoods are located, had higher densities of all three types of food vendors.

\section{Discussion}

In this study the weighted areas with the lowest income had lower densities of food vendors than the weighted areas with middle and high incomes. Areas with higher weighted income tended to have higher densities of butcheries, natural product stores, juice bars, candy shops, snack bars, convenience stores, supermarkets, and bakeries per 1,000 inhabitants. When the healthy and unhealthy food vendors were grouped, the regions also differed statistically, with the higher tertile presenting the highest densities.

Traditionally, higher-income consumers can get around easily while low-income individuals have to conform to nearby food vendors because of their limited transportation options 31 . This difference in the density of food vendors by territorial income may reflect the consumption profile of the population, and consequently, influence the prevalence of overweight/obesity in the regions' residents.

Healthy food vendors in a neighborhood (farmers' markets and grocery stores that sell fruits and vegetables) can reduce the time spent by low-income families on public or other transportation 15 , and facilitate the adoption of a healthy diet 8 , benefitting the most vulnerable population 15 .

The low density or inexistence of healthy food vendors, such as farmers' markets and seafood shops, in some areas of Florianópolis may characterize them as food deserts. The term food desert has been used to denote the absence of food vendors in a given area ${ }^{17}$. Yet, low-income neighborhoods often have a few food vendors, but they only sell foods of low nutritional quality 32 . Hence, food desert in the present study was defined as an area with difficult access to healthy food vendors 5 .

In poorer areas, the inexistence of supermarkets may force the local residents to shop at local grocery stores more frequently, and these stores often sell less healthy foods at higher prices, possibly stimulating the adoption or maintenance of obesogenic diets 14,33 . The density of supermarkets increased as the income tertile of an area increased, and for grocery stores, this relationship was inversed but was not statistically significant.

A study from São Paulo also found that areas of higher income had higher densities of all types of food vendors (supermarkets, grocery stores, farmers' markets, and fast food restaurants) 34. Another study from São Paulo found that fast food restaurants were more likely to be located in neighborhoods with low socioeconomic levels; and supermarkets and restaurants were more likely to be found in neighborhoods with higher socioeconomic levels 35 .

In the city of Belo Horizonte (Minas Gerais State), Mendes 36 found a mean of 0.07 supermarkets/ hypermarkets and 0.05 vegetable and fruit vendors per census tract, not taking into account the population density and using a different unit of analysis than that used herein. Also in Belo Horizonte, 


\section{Figure 2}

Density of healthy, unhealthy, and mixed food vendors by mean nominal household income per month. Florianópolis, Santa Catarina State, Brazil, 2013.

2a) Healthy food vendors

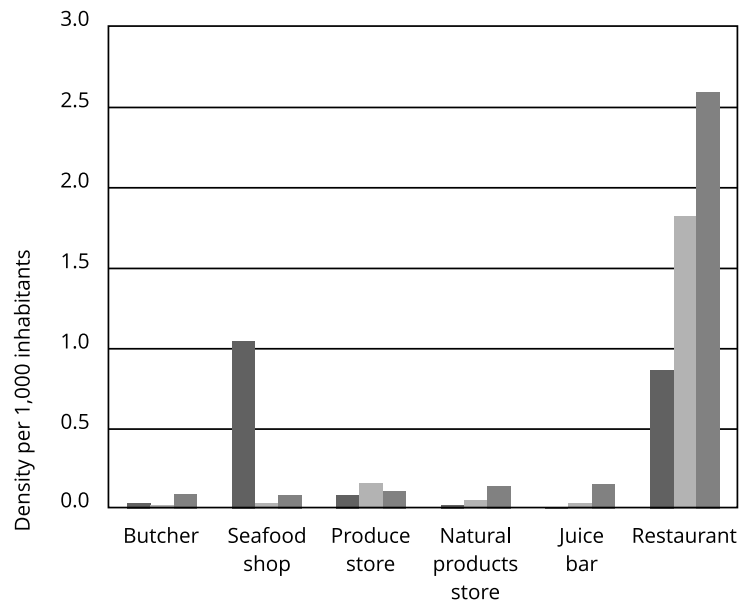

1st income tertile

| 2nd income tertile

3rd income tertile

2b) Unhealthy food vendors

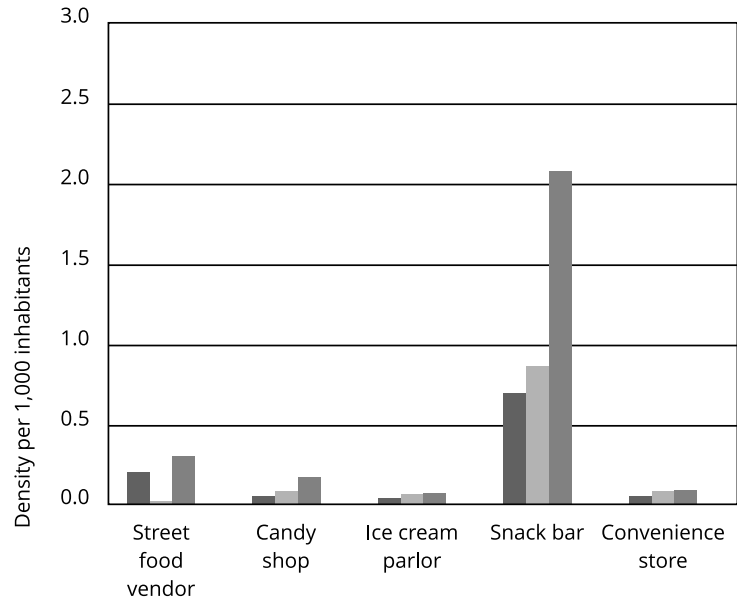

1st income tertile

2nd income tertile

3rd income tertile

2c) Mixed food vendors

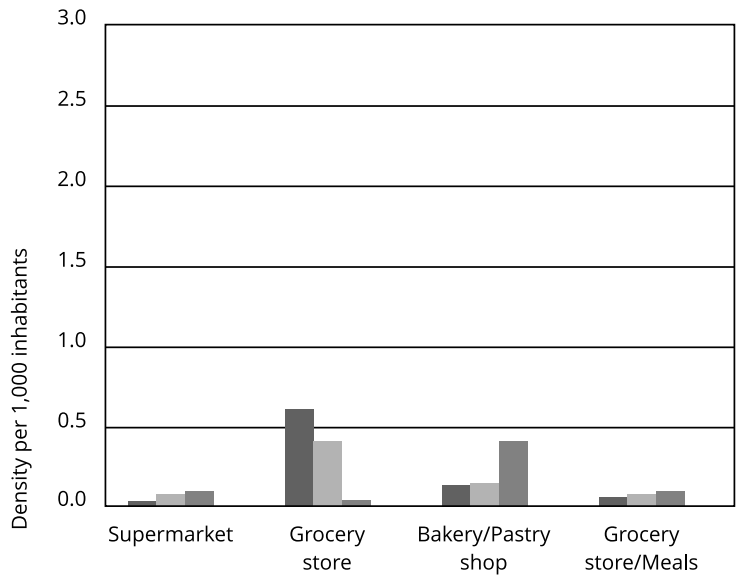

1st income tertile

7 2nd income tertile

3rd income tertile 
Table 1

Mean density of food vendors per 1,000 inhabitants by tertile of mean nominal household income per month in the weighted areas. Florianópolis, Santa Catarina State, Brazil, 2013.

\begin{tabular}{|c|c|c|c|c|}
\hline Type of food vendor & $\begin{array}{l}\text { 1st income tertile } \\
\overline{\mathbf{x}}(\mathrm{SD})\end{array}$ & $\begin{array}{l}\text { 2nd income tertile } \\
\qquad \overline{\mathbf{x}}(\mathrm{SD})\end{array}$ & $\begin{array}{l}\text { 3rd income tertile } \\
\qquad \overline{\mathbf{x}}(\mathrm{SD})\end{array}$ & p-value * \\
\hline \multicolumn{5}{|l|}{ Healthy food vendors } \\
\hline Butcher & $0.03( \pm 0.05)$ & $0.02( \pm 0.05)$ & $0.09( \pm 0.06)$ & $0.044 * *$ \\
\hline Seafood shop & $1.04( \pm 0.63)$ & $0.03( \pm 0.04)$ & $0.08( \pm 0.05)$ & 0.093 \\
\hline Farmers' market & $0.08( \pm 0.04)$ & $0.16( \pm 0.17)$ & $0.11( \pm 0.07)$ & 0.205 \\
\hline Natural products store & $0.02( \pm 0.04)$ & $0.05( \pm 0.07)$ & $0.14( \pm 0.21)$ & $0.017 * \star *$ \\
\hline Juice bar & $0.01( \pm 0.03)$ & $0.03( \pm 0.06)$ & $0.15( \pm 0.24)$ & $0.029 * * *$ \\
\hline Restaurant & $0.86( \pm 0.54)$ & $1.82( \pm 2.55)$ & $2.59( \pm 2.91)$ & $0.110 * * *$ \\
\hline Total & $1.04( \pm 0.63)$ & $2.16( \pm 2.83)$ & $3.21( \pm 3.44)$ & $0.023 * * *$ \\
\hline \multicolumn{5}{|l|}{ Unhealthy food vendors } \\
\hline Street food vendor & $0.02( \pm 0.03)$ & $0.02( \pm 0.03)$ & $0.30( \pm 0.59)$ & 0.529 \\
\hline Candy shop & $0.05( \pm 0.04)$ & $0.08( \pm 0.06)$ & $0.17( \pm 0.25)$ & $0.036 * * *$ \\
\hline Ice cream parlor & $0.04( \pm 0.05)$ & $0.06( \pm 0.06)$ & $0.07( \pm 0.07)$ & $0.290 * \star *$ \\
\hline Snack bar & $0.69( \pm 0.59)$ & $0.86( \pm 0.51)$ & $2.07( \pm 2.54)$ & $0.009 * * *$ \\
\hline Convenience store & $0.05( \pm 0.04)$ & $0.08( \pm 0.03)$ & $0.09( \pm 0.06)$ & $0.021 * * *$ \\
\hline Total & $0.84( \pm 0.69)$ & $1.09( \pm 0.59)$ & $2.69( \pm 3.28)$ & $0.010 * * *$ \\
\hline \multicolumn{5}{|l|}{ Mixed food vendors } \\
\hline Supermarket & $0.03( \pm 0.04)$ & $0.07( \pm 0.06)$ & $0.09( \pm 0.05)$ & $0.019 * * *$ \\
\hline Grocery store & $0.60( \pm 0.45)$ & $0.40( \pm 0.41)$ & $0.33( \pm 0.35)$ & $0.116 * * *$ \\
\hline Bakery/Pastry shop & $0.13( \pm 0.03)$ & $0.14( \pm 0.03)$ & $0.40( \pm 0.40)$ & $0.037 * * *$ \\
\hline Grocery store/meals & $0.05( \pm 0.07)$ & $0.07( \pm 0.05)$ & $0.09( \pm 0.08)$ & $0.235 * * *$ \\
\hline Total & $0.81( \pm 0.49)$ & $0.68( \pm 0.44)$ & $0.91( \pm 0.58)$ & $0.602 * * *$ \\
\hline
\end{tabular}

SD: standard deviation; $\bar{x}$ : mean.

* Kruskal-Wallis test;

** $\mathrm{p}<0.05$ between means 1 st and 3rd income tertile and 2nd and 3rd income tertile;

*** Trend test. 
Figure 3

Density tertiles of healthy, unhealthy, mixed, and all food vendors in the weighted areas. Florianópolis, Santa Catarina State, Brazil, 2013.
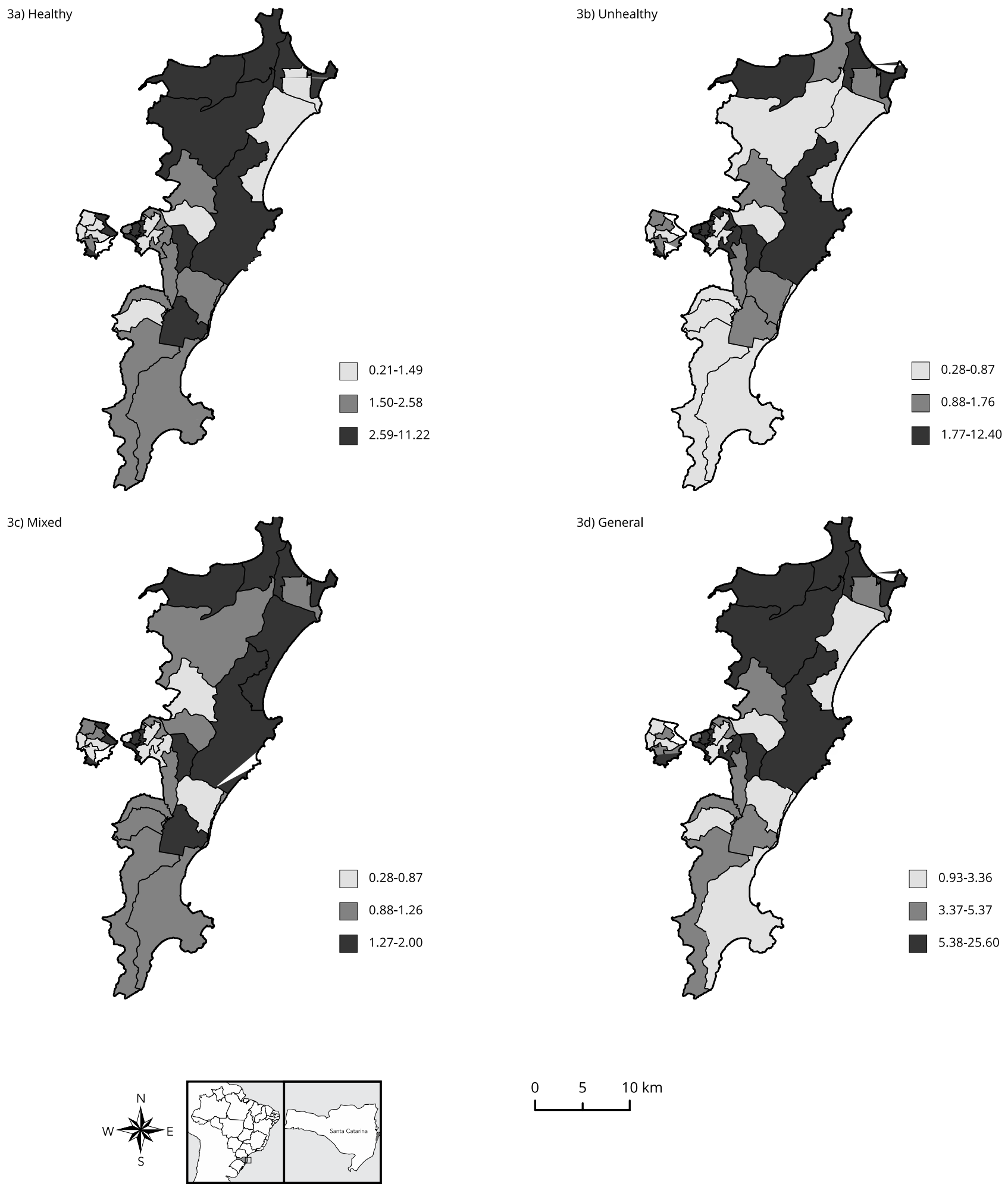
Building supermarkets in food deserts to improve access to healthy foods may not be as effective as offering healthy products at more affordable prices 41 . This is because cost is considered the greatest barrier to a healthy diet, not physical distance or lack of information 42 .

The strategies available to improve access to fresh and healthy foods at affordable prices for the population include attracting and encouraging new grocery stores and supermarkets; increasing the availability of fruits, vegetables, and other healthy foods in small food vendors; encouraging local food production; and promoting the development of cooperatives, farmers' markets, and public markets 32,43 .

Residential and service areas predominate in Florianópolis, indifferent to the rising intensity of urban mobility 44. Even so, in 2014 the new urban master plan of Florianópolis was presented after a long discussion with the population, which did not escape criticism. One of the urban development priorities presented by the plan is neighborhood centrality, eliminating exclusive land use, a factor that until then prevented the existence of small stores in residential areas 44 . Centrality was defined as an urban agglomeration located near the main roads, with mixed activities and businesses 44 .

One example of centrality proposed by the new urban master plan of Florianópolis is that part of the ground floor of buildings with four or more floors must be occupied by businesses. Additionally, the new zoning rules establish that small businesses (warehouses, butchers, fruit stores, grocery stores, minimarkets, drugstores, bookstores, and bakeries, among others) may operate in all municipal urban areas 44 . The creation of business and residential centers will directly affect quality of life in all neighborhoods by making a balanced and sustainable distribution of people and economic activities and reinforcing neighborhood relationships 44 .

Knowledge of the food environment helps to identify intervention points to improve community availability and access to healthy foods 45 . This study did not aim to investigate the types of products sold in Florianópolis, which may generate doubts regarding the quality of foods available in different municipal weighted areas. All the same, classifying food vendors according to the type of food they offer may be considered an indication of product quality.

Lower-income areas had a lower density of healthy food vendors, characterizing the presence of food deserts. Food deserts regard difficult access to fruits and vegetables and easy access to energydense, nutrient-poor foods. Unequal food vendor distribution in areas of higher and lower incomes partly reflects aspects of the social injustice present in Florianópolis, the preferred destination of migrants from the state and other Brazilian states in the last decade.

As a study limitation, it is important to mention that the seasonal nature of food vendors located in tourist areas, such as the northern part of the island, and the existence of informal and illegal food vendors, especially in poorer locations, can mask the real distribution of food vendors in such regions. Additionally, during data collection we sometimes found more than one food vendor listed in business association or government records with the same address, and occasionally a food vendor no longer existed. This type of outdated information was also found by Liese et al. ${ }^{46}$, who also used secondary data.

Another difficulty that may have directly affected the results regards the date on which the data was collected, which may have resulted in an under- or overestimation of the number of active food vendors, especially in lower-income regions, where the informal economy is more widespread, and food vendor underreporting may have influenced the results.

The results may provide a base for future discussions about the associations between food vendor availability and different outcomes, such as nutritional status, food intake, and purchasing habits in Florianópolis.

Availability of healthy food vendors does not guarantee a better diet and consequently, better nutritional status, but it facilitates the adoption of healthier food habits. Knowing the distribution of these food vendors in a territory allows the establishment of public policies that encourage healthy food vendor startups and/or maintenance and prevent traditionally unhealthy food vendor startups in certain regions. In the future it will be possible to follow the changes that occur in the distribution of these food vendors and also to compare the findings with other large cities with similar demographic characteristics. 


\section{Contributors}

E. N. Correa collected, analyzed, and interpreted the data, and conceived and wrote the manuscript. C. M. P. Padez and F. A. G. Vasconcelos reviewed the manuscript. A. H. Abreu analyzed the spatial data and reviewed the manuscript.

\section{Acknowledgments}

E. N. Correa received a research grant from the Fundo de Apoio à Manutenção e ao Desenvolvimento da Educação Superior no Estado de Santa Catarina.

\section{References}

1. Instituto Brasileiro de Geografia e Estatística. Pesquisa de Orçamentos Familiares 2008-2009: antropometria e estado nutricional de crianças, adolescentes no Brasil. Rio de Janeiro: Instituto Brasileiro de Geografia e Estatística; 2010.

2. Ministério da Saúde. VIGITEL Brazil 2013: protective and risk factors for chronic diseases by telephone survey. Brasília: Ministério da Saúde; 2014.

3. Instituto Brasileiro de Geografia e Estatística. Pesquisa Nacional de Saúde do Escolar. Rio de Janeiro: Instituto Brasileiro de Geografia e Estatística; 2013.
4. Motter AF, Vasconcelos FAG, Correa EN, Andrade DF. Pontos de venda de alimentos e associação com sobrepeso/obesidade em escolares de Florianópolis, Santa Catarina, Brasil. Cad Saúde Pública 2015; 31:620-32.

5. Lopez RP. Neighborhood risk factors for obesity. Obesity 2007; 15:2111-9.

6. McKinnon RA, Reedy J, Morrissette MA, Lytle LA, Yaroch AL. Measures of the food environment: a compilation of the literature, 1990-2007. Am J Prev Med 2009; 36(4 Suppl):S124-33. 
7. Ministério da Saúde. Guia alimentar para a população brasileira. Brasília: Ministério da Saúde; 2014.

8. Chum A, Farrell E, Vaivada T, Labetski A, Bohnert A, Selvaratnam I, et al. The effect of food environments on fruit and vegetable intake as modified by time spent at home: a crosssectional study. BMJ Open 2015; 5:e006200.

9. Mejia N, Lightstone AS, Basurto-Davila R, Morales DM, Sturm R. Neighborhood food environment, diet, and obesity among Los Angeles County adults, 2011. Prev Chronic Dis 2015; 12:E143.

10. Rahmanian E, Gasevic D, Vukmirovich I, Lear SA. The association between the built environment and dietary intake - a systematic review. Asia Pac J Clin Nutr 2014; 23:183-96.

11. Williams J, Scarborough P, Matthews A, Cowburn G, Foster C, Roberts N, et al. A systematic review of the influence of the retail food environment around schools on obesity-related outcomes. Obes Rev 2014; 15:359-74.

12. Yan R, Bastian ND, Griffin PM. Association of food environment and food retailers with obesity in US adults. Health Place 2015; 33:19-24.

13. Feng J, Glass TA, Curriero FC, Stewart WF, Schwartz BS. The built environment and obesity: a systematic review of the epidemiologic evidence. Health Place 2010; 16:175-90.

14. Lee H. The role of local food availability in explaining obesity risk among young school-aged children. Soc Sci Med 2012; 74:1193-203.

15. Zick CD, Smith KR, Fan JX, Brown BB, Yamada I, Kowaleski-Jones L. Running to the store? The relationship between neighborhood environments and the risk of obesity. Soc Sci Med 2009; 69:1493-500.

16. Black C, Ntani G, Cooper C, Cummins S, Moon $\mathrm{G}$, Baird J. Measuring the healthfulness of food retail stores: variations by store type and neighbourhood deprivation. Int J Behav Nutr Phys Act 2014; 11:69.

17. Beaulac J, Kristjansson E, Cummins S. A systematic review of food deserts, 1966-2007. Prev Chronic Dis 2009; 6:A105.

18. Michimi A, Wimberly MC. Associations of supermarket accessibility with obesity and fruit and vegetable consumption in the conterminous United States. Int J Health Geogr 2010; 9:49.
19. Cesani MF, Luis MA, Torres MF, Castro LE, Quintero FA, Luna ME, et al. Sobrepeso y obesidad en escolares de Brandsen en relación a las condiciones socioambientales de residencia. Arch Argent Pediatr 2010; 108:294-302.

20. Duarte CS, Chambers EC, Rundle A, Must A. Physical characteristics of the environment and BMI of young urban children and their mothers. Health Place 2010; 16:1182-7.

21. Widener MJ, Metcalf SS, Bar-Yam Y. Dynamic urban food environments: a temporal analisys of access to healthy foods. Am J Prev Med 2011; 41:439-41.

22. Public Health Advisory Committee. Healthy places, healthy lives: urban environments and wellbeing. Wellington: Minister of Health; 2010.

23. Programa das Nações Unidas para o Desenvolvimento. Índice de Desenvolvimento Humano Municipal Brasileiro. Brasília: Programa das Nações Unidas para o Desenvolvimento/Instituto de Pesquisa Econômica Aplicada; 2013.

24. Instituto Brasileiro de Geografia e Estatística. Censo Demográfico 2010: características da população e dos domicílios. Rio de Janeiro: Instituto Brasileiro de Geografia e Estatística; 2011.

25. Sugai MI. Segregação silenciosa: investimentos públicos e dinâmica socioespacial na área conurbada de Florianópolis (1970-2000). Florianópolis: Editora da UFSC; 2015.

26. Wang MC, Kim S, Gonzalez AA, MacLeod KE, Winkleby MA. Socioeconomic and food-related physical characteristics of the neighbourhood environment are associated with body mass index. J Epidemiol Community Health 2007; 61:491-8.

27. Secretaria Municipal da Casa Civil. Decreto no 12.316 , de 12 de novembro de 2013. Altera a redação dos artigos 3o e 6o do Decreto no $11.864 / 2013$, que dispõe sobre o comércio ambulante e dá outras providências. Diário Oficial Eletrônico do Município de Florianópolis 2013; (1097). http://www.pmf.sc.gov.br/arqui vos/diario/pdf/18_11_2013_20.53.58.360c7d 1feb9603d738c761b90fa6239a.pdf. 
28. Monteiro CA, Levy RB, Claro RM, Castro IRR, Cannon G. A new classification of foods based on the extent and purpose of their processing. Cad Saúde Pública 2010; 26:2039-49.

29. Monteiro CA, Cannon G, Levy R, Moubarac J-C, Jaime P, Martins AP, et al. NOVA. The star shines bright. World Nutrition 2016; 7:28-38.

30. Wilson JS, Kelly CM. Measuring the quality of public open space using Google Earth: a commentary. Am J Prev Med 2011; 40:276-7.

31. Siqueira LF. Análise sócio-espacial da localização de equipamentos públicos de abastecimento alimentar urbano: estudo de caso em Florianópolis-SC [Dissertação de Mestrado]. Florianópolis: Programa de Pós-graduação em Enhenharia Civil, Universidade Federal de Santa Catarina; 2000.

32. Dannenberg AL, Frumkin H, Jackson RJ. Making healthy places: designing and building for health, well-being, and sustainability. Washington DC: Island Press; 2001.

33. Burton LM, Kemp SP, Leung M, Matthews SA, Takeuchi DT, editors. Communities, neighborhoods, and health: expanding the boundaries of place. New York: Springer; 2011.

34. Jaime PC, Duran AC, Sarti FM, Lock K. Investigating environmental determinants of diet, physical activity, and overweight among adults in Sao Paulo, Brazil. J Urban Health 2011; 88:567-81.

35. Duran AC, Diez Roux AV, Latorre MR, Jaime PC. Neighborhood socioeconomic characteristics and differences in the availability of healthy food stores and restaurants in Sao Paulo, Brazil. Health Place 2013; 23:39-47.

36. Mendes LL. Ambiente construído e ambiente social - associações com o excesso de peso em adultos [Tese de Doutorado]. Belo Horizonte: Universidade Federal de Minas Gerais; 2012.

37. Pessoa MC. Ambiente alimentar e consumo de frutas, legumes e verduras em adultos de Belo Horizonte-MG. Belo Horizonte: Universidade Federal de Minas Gerais; 2013.

38. Leete L, Bania N, Sparks-Ibanga A. Congruence and coverage: alternative approaches to identifying urban food deserts and food hinterlands. Journal of Planning Education and Research 2012; 32:204-18.
39. Shier V, An R, Sturm R. Is there a robust relationship between neighbourhood food environment and childhood obesity in the USA? Public Health 2012; 126:723-30.

40. Sutherland LA, Kaley LA, Leslie F. Guiding stars: the effect of a nutrition navigation program on consumer purchases at the supermarket. Am J Clin Nutr 2010; 91:1090S-4S.

41. Ghosh-Dastidar B, Cohen D, Hunter G, Zenk SN, Huang C, Beckman R, et al. Distance to store, food prices, and obesity in urban food deserts. Am J Prev Med 2014; 47:587-95.

42. Alkon AH, Block D, Moore K, Gillis C, DiNuccio N, Chavez N. Foodways of the urban poor. Geoforum 2013; 48:126-35.

43. Treuhaft S, Karpyn A. The grocery gap: who has access to healthy food and why it matters. Oakland: PolicyLink/The Food Trust; 2010.

44. Prefeitura Municipal de Florianópolis. Lei Complementar no 482, de 17 de janeiro de 2014. Institui o Plano Diretor de Urbanismo do Município de Florianópolis que dispõe sobre a política de desenvolvimento urbano, o plano de uso e ocupação os instrumentos urbanisticos e o sistema de gestão. http://www.pmf.sc.gov.br/ arquivos/arquivos/pdf/04_02_2014_12.01.39. ae8afdb369c91e13ca6efcc14b25e055.pdf.

45. Kelly B, Flood VM, Yeatman H. Measuring local food environments: an overview of available methods and measures. Health Place 2011; 17:1284-93.

46. Liese AD, Colabianchi N, Lamichhane AP, Barnes TL, Hibbert JD, Porter DE, et al. Validation of 3 food outlet databases: completeness and geospatial accuracy in rural and urban food environments. Am J Epidemiol 2010; 172:1324-33. 


\section{Resumo}

Os objetivos desse estudo foram identificar o perfil de distribuição de comerciantes de alimentos no Município de Florianópolis, Santa Catarina, Brasil, e investigar a associação com as características das diferentes regiões do município. O estudo transversal, descritivo, obteve a localização dos comerciantes de alimentos a partir de dados secundários de diferentes fontes institucionais. Foi calculada a densidade dos diferentes tipos de comerciantes por mil habitantes em cada área ponderada do município. O teste de Kruskal-Wallis foi usado para comparar a densidade média de comerciantes de alimentos com as regiões do município, ponderadas por renda. As áreas de menor renda tiveram a menor densidade de açougueiros, lanchonetes, supermercados, padarias/pastelarias, lojas de produtos naturais, lojas de sucos e lojas de conveniência. A identificação dessas áreas pode incentivar a elaboração de políticas públicas que facilitem empreendimentos novos de comercialização de alimentos saudáveis e/ou a manutenção dos estabelecimentos de alimentos saudáveis, principalmente nas áreas de menor renda.

Comercialização de Produtos; Urbanização; Alimentos

\section{Resumen}

Los objetivos de este estudio fueron identificar el perfil de distribución de comerciantes de alimentos en el municipio de Florianópolis, Santa Catarina, Brasil, e investigar la asociación con las características de las diferentes regiones del municipio. El estudio transversal, descriptivo, obtuvo la localización de los comerciantes de alimentos, a partir de datos secundarios de diferentes fuentes institucionales. Se calculó la densidad de los diferentes tipos de comerciantes por 1.000 habitantes en cada área ponderada del municipio. El test de KruskalWallis se usó para comparar la densidad media de comerciantes de alimentos con las regiones del municipio, ponderadas por renda. Las áreas de menor renta tuvieron la menor densidad de carnicerías, bares de aperitivos, supermercados, panaderías/ bocaterías, tiendas de productos naturales, tiendas de zumos y tiendas 24hrs. La identificación de esas áreas puede incentivar la elaboración de politicas públicas que faciliten emprendimientos nuevos de comercialización de alimentos saludables y/o el mantenimiento de los establecimientos de alimentos saludables, principalmente en las áreas de menor renta.

Comercialización de Productos; Urbanización; Alimentos
Submitted on $05 /$ Sep/2015

Final vesion resubmitted on 19/Apr/2016

Approved on 02/May/2016 